\title{
PENGEMBANGAN E-MODUL (MODEL UNIT LESSOM) DI DAERAH MINIM INTERNET BERBASIS KEMAMPUAN BERPIKIR HIPOTETIKAL DEDUKTIF
}

\author{
Jayati $^{1}$, Suparwoto ${ }^{2}$, Moh. Toifur ${ }^{3)}$ \\ 1,3)Magister Pendidikan Fisika, Universitas Ahmad Dahlan, Yogyakarta, Jawa Tengah, Indonesia \\ 2)Pendidikan Fisika, Universitas Negeri Yogyakarta, Yogyakarta, Jawa Tengah, Indonesia \\ Corresponding author : Jayati \\ E-mail : jayatispd809@gmail.com
}

Diterima 23 November 2021, Direvisi 24 November 2021, Disetujui 25 November 2021

\begin{abstract}
ABSTRAK
Pembelajaran jarak jauh dengan menggunakan daring tidak sepenuhnya dapat dilakukan pada wilayah minim internet, dan sistem penugasan belum dapat memberikan hasil pemahaman dan hasil belajar siswa meningkat. Tujuan penelitian ini adalah mengembangkan e-modul berbasis kemampuan berfikir hipotetikal deduktif pada daerah minim internet dengan topik hukum Newton tentang gravitasi. Metode yang dilakukan adalah melakukan validasi hasil pengembangan modul dengan empat validator yang terdiri dari dosen dan guru. Angket validasi e-modul berupa validasi materi dan validasi produk. Responden yang diujikan sebanyak 23 orang menggunakan kuisioner respon siswa. Hasil penelitian menunjukkan bahwa validasi materi memiliki nilai reliabilitas sebesar 0.8 dan valiadi produk memiliki nilai reliabilitas sebesar 0.64 . Hasil analisis keefektifan e-modul yang diberikan kepada peserta didik diperoleh skor rata- rata 3.5. Skor ini masuk dalam kategori efektif.
\end{abstract}

Kata kunci: E-modul; Kemampuan Berfikir Hipotetikal Deduktif; Validasi; Respon Siswa; Kuisioner

\begin{abstract}
Distance learning using online is not fully possible in areas with minimal internet, and the assignment system has not been able to provide understanding results and increase student learning outcomes. The purpose of this research is to develop an e-module based on hypothetical deductive thinking skills in a minimal internet area with the topic of Newton's law of gravity. The method used is to validate the results of the module development with four validators consisting of lecturers and teachers. The emodule validation questionnaire is in the form of material validation and product validation. The respondents who were tested were 23 people using a student response questionnaire. The results showed that material validation had a reliability value of 0.8 and product validation had a reliability value of 0.64 . The results of the analysis of the effectiveness of the e-module given to students obtained an average score of 3.5. This score is included in the effective category.
\end{abstract}

Keywords: E-module; Hypothetical Deductive Thinking Ability; Validation; Student Response; Questionnaire

\section{PENDAHULUAN}

Aktivitas pembelajaran merupakan hal fundamental sebagai proses dalam mengidentifikasi masalah. Hal ini dapat dilakukan karena adanya interaksi antara pendidik dan peserta didik (Umayah \& Riwanto, 2020; Yuangga \& Sunarsi, 2020). Salah satu komponen yang memiliki andil besar dalam mewujudkan lingkungan belajar adalah pendidik, yang mana dituntut lebih peka terhadap pergeseran lingkungan belajar saat ini seperti rendahnya mutu pendidikan (Ekayani, 2021; Lawson, 2003). Kompleksitas tantangaan di masa depan telah direkomendasi oleh UNESCO yaitu pembelajaran abad 21 yang idealnya adalah arah pembelajaran harus mengarah kepada empat komponen yakni communication, collaboration, critical thinking dan problem solving, creativity dan innovation (Gunawan \& Widiati, 2019; Suciati et al., 2014). Permasalahan pendidikan di Indonesia saat ini merupakan polemik yang cukup besar dan menjadi perhatian serius oleh para pakar pendidikan (Dhema \& Jufriansah, 2021). Pada hasil penelitian setidaknya ada beberapa masalah pendidik yang dihadapi di Indonesia, yaitu kualitas guru, kesejahteraan guru, politisasi guru dan yang terjadi saat ini adalah ketika terjadi wabah Covid 19 yang mengharuskan pembatasan proses belajar mengajar (Sari \& Haryono, 2021). Masalah tersebut akan sangat berpengaruh pada kinerja dan kualitas ketika pembelajaran abad ke- 21 yang menuntut seorang pendidik mempunyai 
kualitas lebih bukan saja bersaing di dunia pendidikan indonesia tapi pada dunia pendidikan di sesama negara ASEAN bahkan diluar negara ASEAN. Selain hal tersebut adanya faktor esternal dan internal dalam dunia pendidikan turut menentukan kualitas dari seorang pendidik (Sulisworo, 2016).

Umumnya, guru mata pelajaran fisika mengajarkan kemampuan kepada peserta didik hanya sebatas berpikir pada pengetahuan deklaratif. (Çavdar \& Doe, 2012; Sukaisih et al., 2020). Pola berpikir seseorang secara psikologi dalam memecahkan masalah sebetulnya telah menggambarkan kemampuannya. Hanya saja belum terbiasa dan terampil dalam menggunakannya, sehingga dalam menyelesaikan masalah seperti ini, salah satu pola berpikir dalam pemecahan masalah adalah berpikir hipotetikal deduktif. Penerapannya, pola berpikir tersebut digunakan untuk mencari tahu jawaban suatu fenomena alam (memecahkan masalah) yang berhubungan dengan fisika melalui arahan dari pendidik (Octaviani et al., 2015). Untuk membantu keterlaksanaan, maka perlu diterapkan media yang tepat untuk menumbuhkan kreativitas, yang dapat membantu motivasi peserta didik dalam belajar (Ramadoan \& Sulisworo, 2018).

Pada era pandemi Covid-19, perkembangan pendidikan dihadapkan pada permasalahan baru, dimana hampir diseluruh kebijakan dalam pelaksanaan proses pendidikan berubah. Perubahan yang lebih menonjol terlihat pada pemercepatan penggunaan teknologi sebagai pemenuhan pada proses belajar mengajar dan tujuan pendidikan (Wahyuningsih et al., 2021). Seiring dengan masa pandemi yang belum dapat diketahui, Pembelajaran Jarak Jauh (PJJ) menjadi alternatif pengganti pertemuan tatap muka di kelas (Anugrahana, 2020). Namun hal ini terbentur ketika dihadapkan pada kondisi daerah yang minim internet dan fasilitas elektronik yang tidak memadai. Salah satunya adalah SMA Negeri yang ada di kabupaten Muna, Sulawesi Tenggara berada di desa Labuan memiliki jumlah kelas 11 kelas, dengan fasilitas laboratorium yang kurang lengkap dan dimanfaatkan secara kurang optimal. Selama masa pandemi Covid-19 pihak sekolah menerapkan pembelajaran dengan pemberian penugasan. Berdasarkan hal tersebut, maka tujuan penelitian ini adalah pengembangan $e$ modul (model unit lesson) berbasis kemampuan berpikir hipotetikal deduktif untuk meningkatkan hasil belajar peserta didik. Penelitian ini diharapkan akan memberikan solusi minimnya internet untuk pembelajaran PJJ

\section{METODE PENELITIAN}

Penelitian ini termasuk dalam penelitian pengembangan dengan menggunakan model 4-D (Nuniati et al., 2021). Ada empat validator yang digunakan sebagai sampel yaitu dua dosen yang memiliki kapabilitas pendidikan dan guru senior. Instrumen yang digunakan pada penelitian ini terdiri dari, instrument tahap validasi materi dan validasi produk selengkapnya disajikan pada tabel 1 dan tabel 2. Sedangkan instrument tahap uji coba berupa instrumen respon siswa seabagi pengguna $e$ modul. Indikator respon siswa seperti pada tabel 3.

Tabel 1. Angket validasi materi

\begin{tabular}{|c|c|c|}
\hline Variabel & $\begin{array}{c}\text { Sub } \\
\text { variabel }\end{array}$ & Indikator \\
\hline \multirow{5}{*}{ Kualitas isi } & \multirow{3}{*}{ Ketepatan } & $\begin{array}{l}\text { Ketepatan } \\
\text { materi }\end{array}$ \\
\hline & & Ketepatan soal \\
\hline & & $\begin{array}{l}\text { Ketepatan } \\
\text { pemberian } \\
\text { contoh nyata }\end{array}$ \\
\hline & \multirow[b]{2}{*}{$\begin{array}{l}\text { Kebahasaa } \\
\mathrm{n}\end{array}$} & Bahasa jelas \\
\hline & & $\begin{array}{l}\text { Bahasa mudah } \\
\text { dimengerti }\end{array}$ \\
\hline \multirow{4}{*}{$\begin{array}{l}\text { Kualitas } \\
\text { instruksional }\end{array}$} & \multirow{3}{*}{$\begin{array}{l}\text { Dapat } \\
\text { memberika } \\
\text { n dampak } \\
\text { bagi siswa }\end{array}$} & $\begin{array}{l}\text { Kegiatan dapa } \\
\text { meningkatkan }\end{array}$ \\
\hline & & $\begin{array}{l}\text { hasil belajar } \\
\text { siswa }\end{array}$ \\
\hline & & $\begin{array}{l}\text { Kagiatan dapa } \\
\text { meningkatkan } \\
\text { rasa ingin tahu } \\
\text { siswa }\end{array}$ \\
\hline & $\begin{array}{l}\text { Memberika } \\
\mathrm{n} \text { dampak } \\
\text { guru }\end{array}$ & $\begin{array}{l}\text { Kegiatan yang } \\
\text { digunakan } \\
\text { mendukung } \\
\text { bahan ajar lain }\end{array}$ \\
\hline \multicolumn{3}{|c|}{ Tabel 2. Angket validasi produk } \\
\hline \multicolumn{2}{|l|}{ Komponen } & Indikator \\
\hline $\begin{array}{l}\text { Practical } \\
\text { (praktis) }\end{array}$ & $\begin{array}{l}\text { Mudah } \\
\text { mana }\end{array}$ & dibawa kemana- \\
\hline \multirow[b]{2}{*}{ Jenis huruf } & Size hur & uf mudah dibaca \\
\hline & $\begin{array}{l}\text { Pemiliha } \\
\text { sesuai }\end{array}$ & n warna huruf \\
\hline $\begin{array}{l}\text { Availability } \\
\text { (tersedianya } \\
\text { bahan) }\end{array}$ & $\begin{array}{l}\text { Tersedia } \\
\text { untuk } \mathrm{m}\end{array}$ & $\begin{array}{l}\text { anya aplikasi } \\
\text { embuat e-modul }\end{array}$ \\
\hline Cost (biaya) & $\begin{array}{l}\text { Tidak } \\
\text { membut }\end{array}$ & $\begin{array}{r}\text { terlalu } \\
\text { uhkan biaya besar }\end{array}$ \\
\hline $\begin{array}{l}\text { Physical } \\
\text { condition } \\
\text { (kondisi fisik) }\end{array}$ & $\begin{array}{l}\text { Bentuk } \\
\text { jelas }\end{array}$ & e-modul harus \\
\hline $\begin{array}{l}\text { Accessibility to } \\
\text { student (mudah } \\
\text { dicapai) }\end{array}$ & $\begin{array}{ll}\text { to } & \text { Dwifung } \\
\text { lah } & \text { dapat } \\
\text { siswa }\end{array}$ & $\begin{array}{l}\text { si, yaitu guru } \\
\text { nenggunakannya, } \\
\text { juga semakin }\end{array}$ \\
\hline
\end{tabular}




\begin{tabular}{|c|c|}
\hline & $\begin{array}{l}\text { mudah } \\
\text { pelajaran }\end{array}$ \\
\hline $\begin{array}{l}\text { Emotional } \\
\text { impact (dampak } \\
\text { emosional) }\end{array}$ & $\begin{array}{ll}\text { Mempunyai nilai estetika } \\
\text { sehingga akan lebih } \\
\text { menarik }\end{array}$ \\
\hline $\begin{array}{l}\text { Student } \\
\text { characteristics } \\
\text { (watak siswa) }\end{array}$ & $\begin{array}{l}\text { Sesuai dengan karakter } \\
\text { siswa meliputi masalah } \\
\text { tingkat kematangan siswa } \\
\text { secara komprehensif }\end{array}$ \\
\hline \multirow{5}{*}{$\begin{array}{l}\text { Student } \\
\text { relevance } \\
\text { (sesuai dengan } \\
\text { siswa) }\end{array}$} & $\begin{array}{l}\text { Meningkatkan } \\
\text { pengalaman siswa }\end{array}$ \\
\hline & $\begin{array}{l}\text { Untuk siswa SMA/MA } \\
\text { upayakan untuk membuat } \\
\text { kalimat yang tidak terlalu }\end{array}$ \\
\hline & $\begin{array}{l}\text { panjang, maksimal } 25 \\
\text { kata perkalimat dan dalam } \\
\text { satu paragraf } 3-7 \text { kalimat }\end{array}$ \\
\hline & $\begin{array}{l}\text { Mengembangkan pola } \\
\text { pikir siswa }\end{array}$ \\
\hline & $\begin{array}{l}\text { Penyajian kalimat yang } \\
\text { disesuaikan dengan usia } \\
\text { dan pengalaman } \\
\text { pembacanya }\end{array}$ \\
\hline $\begin{array}{l}\text { Student } \\
\text { involvement } \\
\text { (keterlibatan } \\
\text { siswa) }\end{array}$ & $\begin{array}{l}\text { Memberikan keterlibatan } \\
\text { siswa (peran aktif siswa) }\end{array}$ \\
\hline \multirow{2}{*}{$\begin{array}{l}\text { Relevance to } \\
\text { basic } \\
\text { competencies } \\
\text { (relevansi } \\
\text { dengan KD) }\end{array}$} & $\begin{array}{l}\text { Judul diturunkan dari } \\
\text { kompetensi dasar }\end{array}$ \\
\hline & $\begin{array}{l}\text { Relevan dengan KD yang } \\
\text { harus dikuasai oleh siswa }\end{array}$ \\
\hline $\begin{array}{l}\text { Content } \\
\text { presentation } \\
\text { (presentasi isi) }\end{array}$ & $\begin{array}{l}\text { Memberikan informasi } \\
\text { secara lengkap tentang } \\
\text { hal-hal yang penting } \\
\text { sebagai informasi }\end{array}$ \\
\hline
\end{tabular}

\begin{tabular}{llr}
\hline & $\begin{array}{l}\text { Materi harus sesuai } \\
\text { dengan target sasaran } \\
\text { yang dituju }\end{array}$ \\
& $\begin{array}{l}\text { Kebenaran mataeri dapat } \\
\text { dipertanggungjawabkan }\end{array}$ \\
\hline $\begin{array}{l}\text { Teacher } \\
\text { utilization } \\
\text { (pemanfaatan } \\
\text { guru) }\end{array}$ & $\begin{array}{l}\text { E-modul memiliki segi } \\
\text { kemanfaatan }\end{array}$ \\
\hline $\begin{array}{l}\text { Teacher } \\
\text { solution }\end{array}$ & $\begin{array}{l}\text { E-modalajaran } \\
\text { masalah }\end{array}$ \\
\hline
\end{tabular}

\begin{tabular}{cl}
\hline No. & \multicolumn{1}{c}{ Indikator } \\
\hline 1 & Kemanfaatan \\
\hline 2 & Kemudahan pemakaian \\
\hline 3 & Kemudahan mempelajari \\
\hline 4 & Kepuasan \\
\hline
\end{tabular}

\section{HASIL DAN PEMBAHASAN}

Hasil pengembangan produk e-modul ditampilkan pada gambar 1 .

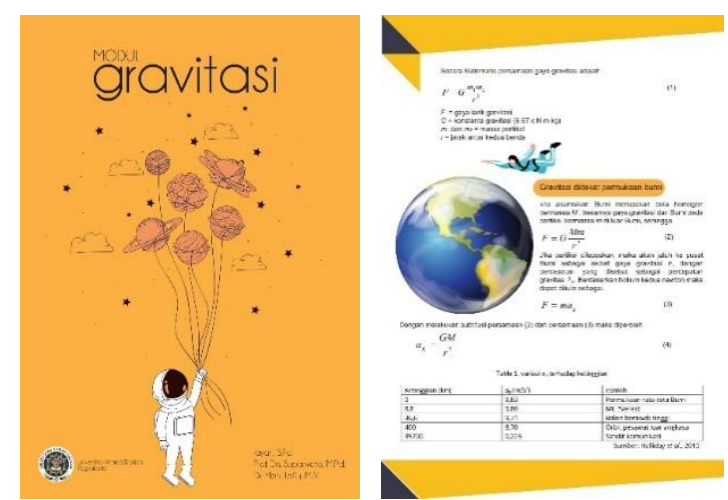

Gambar 1. Hasil desain pengembangan emodul

Tabel 4. Hasil validasi materi

\begin{tabular}{|c|c|c|c|c|c|c|c|c|c|c|c|c|c|c|c|}
\hline \multirow{2}{*}{ Validator } & \multicolumn{6}{|c|}{ Ketepatan } & \multicolumn{4}{|c|}{ Kebahasaan } & \multicolumn{5}{|c|}{$\begin{array}{l}\text { Dapat memberikan } \\
\text { dampak bagi siswa }\end{array}$} \\
\hline & 1 & 2 & 3 & 4 & 5 & 6 & 7 & 8 & 9 & 10 & 11 & 12 & 13 & 14 & 15 \\
\hline I & 3 & 3 & 3 & 3 & 3 & 3 & 4 & 4 & 3 & 4 & 3 & 3 & 3 & 3 & 3 \\
\hline II & 4 & 4 & 3 & 3 & 3 & 4 & 4 & 3 & 3 & 4 & 3 & 3 & 3 & 4 & 4 \\
\hline III & 4 & 4 & 4 & 3 & 4 & 3 & 4 & 3 & 3 & 4 & 4 & 3 & 4 & 4 & 4 \\
\hline \multirow[t]{5}{*}{ IV } & 4 & 4 & 4 & 3 & 4 & 3 & 4 & 4 & 4 & 4 & 3 & 4 & 3 & 4 & 4 \\
\hline & 0 & 0 & 0 & 0 & 0 & 0 & 0 & 0 & 0 & 0 & 0 & 0 & 0 & 0 & 0 \\
\hline & 0 & 0 & 0 & 0 & 0 & 0 & 0 & 0 & 0 & 0 & 0 & 0 & 0 & 0 & 0 \\
\hline & 1 & 1 & 2 & 4 & 2 & 3 & 0 & 2 & 3 & 0 & 3 & 3 & 3 & 1 & 1 \\
\hline & 3 & 3 & 2 & 0 & 2 & 1 & 4 & 2 & 1 & 4 & 1 & 1 & 1 & 3 & 3 \\
\hline V & 1 & 1 & 1 & 1 & 1 & 1 & 1 & 1 & 1 & 1 & 1 & 1 & 1 & 1 & 1 \\
\hline Vrata & 1 & & & & & & & & & & & & & & \\
\hline Vmin & 1 & & & & & & & & & & & & & & \\
\hline
\end{tabular}


Tabel 5. Hasil validasi produk

\begin{tabular}{|c|c|c|c|c|c|c|c|c|c|c|c|c|c|c|c|c|c|c|c|c|c|}
\hline \multirow[t]{2}{*}{ Validator } & \multicolumn{3}{|c|}{$\begin{array}{c}\text { Pertimbanga } \\
\text { n konteks } \\
\text { (kemasan) }\end{array}$} & \multicolumn{5}{|c|}{$\begin{array}{l}\text { Pertimbangan } \\
\text { produksi }\end{array}$} & \multicolumn{6}{|c|}{ Pertimbangan siswa } & \multicolumn{5}{|c|}{ Pertimbangan materi } & \multicolumn{2}{|c|}{$\begin{array}{c}\text { Pertimb } \\
\text { angan } \\
\text { guru }\end{array}$} \\
\hline & 1 & 2 & 3 & 4 & 5 & 6 & 7 & 8 & 9 & 10 & 11 & 12 & 13 & 14 & 15 & 16 & 17 & 18 & 19 & 20 & 21 \\
\hline I & 4 & 4 & 3 & 3 & 4 & 4 & 4 & 4 & 3 & 4 & 3 & 3 & 4 & 4 & 4 & 4 & 4 & 4 & 4 & 4 & 4 \\
\hline II & 3 & 4 & 4 & 4 & 4 & 3 & 3 & 3 & 4 & 3 & 4 & 3 & 3 & 4 & 3 & 3 & 3 & 3 & 3 & 4 & 4 \\
\hline III & 4 & 3 & 4 & 4 & 4 & 4 & 4 & 4 & 3 & 4 & 3 & 4 & 4 & 3 & 3 & 4 & 4 & 4 & 4 & 4 & 4 \\
\hline \multirow[t]{5}{*}{ IV } & 4 & 4 & 3 & 3 & 3 & 4 & 4 & 4 & 3 & 4 & 3 & 3 & 4 & 4 & 3 & 3 & 3 & 4 & 4 & 3 & 3 \\
\hline & 0 & 0 & 0 & 0 & 0 & 0 & 0 & 0 & 0 & 0 & 0 & 0 & 0 & 0 & 0 & 0 & 0 & 0 & 0 & 0 & 0 \\
\hline & 0 & 0 & 0 & 0 & 0 & 0 & 0 & 0 & 0 & 0 & 0 & 0 & 0 & 0 & 0 & 0 & 0 & 0 & 0 & 0 & 0 \\
\hline & 1 & 1 & 2 & 2 & 1 & 1 & 1 & 1 & 3 & 1 & 3 & 3 & 1 & 1 & 3 & 2 & 2 & 1 & 1 & 1 & 1 \\
\hline & 3 & 3 & 2 & 2 & 3 & 3 & 3 & 3 & 1 & 3 & 1 & 1 & 3 & 3 & 1 & 2 & 2 & 3 & 3 & 3 & 3 \\
\hline V & 1 & 1 & 1 & 1 & 1 & 1 & 1 & 1 & 1 & 0.9 & 1 & 1 & 1 & 1 & 1 & 1 & 1 & 1 & 1 & 1 & 1 \\
\hline Vrata & 1 & & & & & & & & & & & & & & & & & & & & \\
\hline$V \min$ & 1 & & & & & & & & & & & & & & & & & & & & \\
\hline
\end{tabular}

Penyusunan angket didasarkan pada kisi-kisi yang telah disusun sebelumnya oleh peneliti sesuai sumber referensi. Langkah yang dilakukan adalah melakukan validasi terhadap e-modul berbasis hipotetikal deduktif kepada ahli materi dan ahli produk yang terdiri dari dosen ahli fisika dan guru fisika di sekolah (Yuangga \& Sunarsi, 2020). Validasi dilakukan oleh 4 validator dengan hasil yang ditunjukkan pada tabel 4 dan tabel 5 .

Berdasarkan hasil validasi materi diproleh bahwa nilai Viken $(\mathrm{V})$ rata rata sebesar
1 dan validasi produk juga menunjukkan nilai yang sama. Hal ini menandakan bahwa materi dan produk yang dikembangkan valid berdasarkan nilai setiap item yang diperoleh dari validator. Selanjutnya dilakukan uji reliabilitas kepada butir angket. Instrumen angket disusun menggunakan skala ordinal, yaitu menggunakan pernyataan, "sangat setuju", "setuju", "tidak setuju", dan "sangat tidak setuju".

Tabel 6 dan tabel 7 menampilkan hasil reliabilitas dari angket validasi materi dan angket validasi produk.

Tabel 6. Reliabilitas angket validasi materi

\begin{tabular}{|c|c|c|c|c|c|c|c|c|c|c|c|c|c|c|c|}
\hline Var & 0.3 & 0.3 & 0.3 & 0.0 & 0.3 & 0.3 & 0.0 & 0.3 & 0.3 & 0.0 & 0.3 & 0.3 & 0.3 & 0.3 & 0.3 \\
\hline $\begin{array}{l}\text { Jumlah Var } \\
\text { item }\end{array}$ & 3.3 & & & & & & & & & & & & & & \\
\hline $\begin{array}{l}\text { Jumlah Var } \\
\text { total }\end{array}$ & 12.9 & & & & & & & & & & & & & & \\
\hline Reliabilitas & 0.80 & & & & & & & & & & & & & & \\
\hline
\end{tabular}

Tabel 7. Reliabilitas angket validasi produk

\begin{tabular}{|c|c|c|c|c|c|c|c|c|c|c|c|}
\hline$i$ & 1 & 2 & 3 & 4 & 5 & 6 & 7 & 8 & 9 & 10 & 11 \\
\hline Var & 0.3 & 0.3 & 0.3 & 0.3 & 0.3 & 0.3 & 0.3 & 0.3 & 0.3 & 0.3 & 0.3 \\
\hline$i$ & 12 & 13 & 14 & 15 & 16 & 17 & 18 & 19 & 20 & 21 & \\
\hline Var & 0.3 & 0.3 & 0.3 & 0.3 & 0.3 & 0.3 & 0.3 & 0.3 & 0.3 & 0.3 & \\
\hline Jumlah Var item & 5.6 & & & & & & & & & & \\
\hline Jumlah Var total & 14.3 & & & & & & & & & & \\
\hline Reliabilitas & 0.64 & & & & & & & & & & \\
\hline
\end{tabular}

Berdasarkan hasil yang diperoleh bahwa reliabilitas angket validasi materi dan produk dengan nilai lebih dari 0.6. Hal ini menunjukkan bahwa data validasi adalah reliabel (Nuniati et al., 2021). Data yang telah diperoleh selanjutnya ditabulasikan, dan menghitung skor total rata-rata yang ditunjukkan oleh gambar 2, gambar 3 dan gambar 4. Pada gambar 2, hasil validasi produk menunjukkan bahwa analisis kelayakan pada 
item kemasan seebesar 3,7, pertimbangaan produksi sebesar 3.7 , pertimbangan siswa sebesar 3.5, pertimbangan materi sebesar 3.6, pertimbangan guru sebesar sebesar 3.8 dana rata rata keseluruhan item sebesar 3.6 dari skor maksimal 4. Berdasarkan hasil ini menunjukkan bahwa hasil validasi produk pada kategori sangat layak digunakan. sedangkan gambar 3 diperoleh bahwa hasil validasi materi berdasarkan analisis kelayakan e-modul setiap item penialian adalah ketepatan sebesar 3.5, kebahasaan sebesar 3.7 dan dampak kepada siswa sebesar 3.5. Rata rata validasi materi sebesar 3.5 dari skor maksimal 4, maka validasi materi dalam kategori sangat layak digunakan.

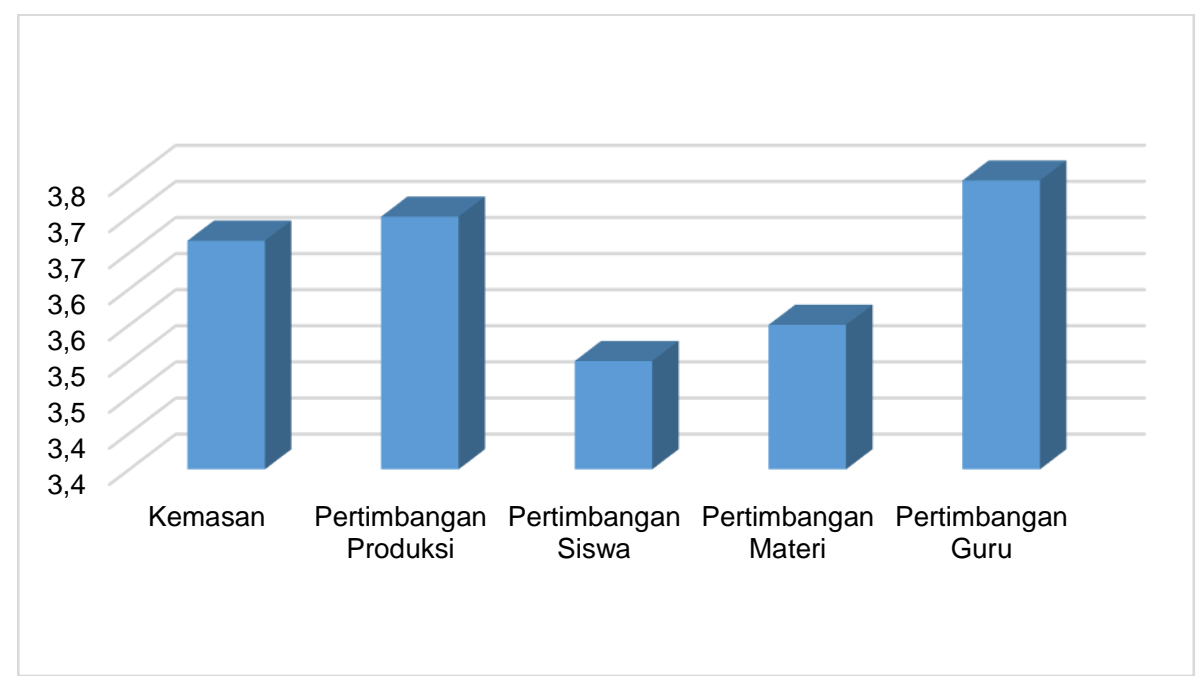

Gambar 2. Rerata skor validasi produk

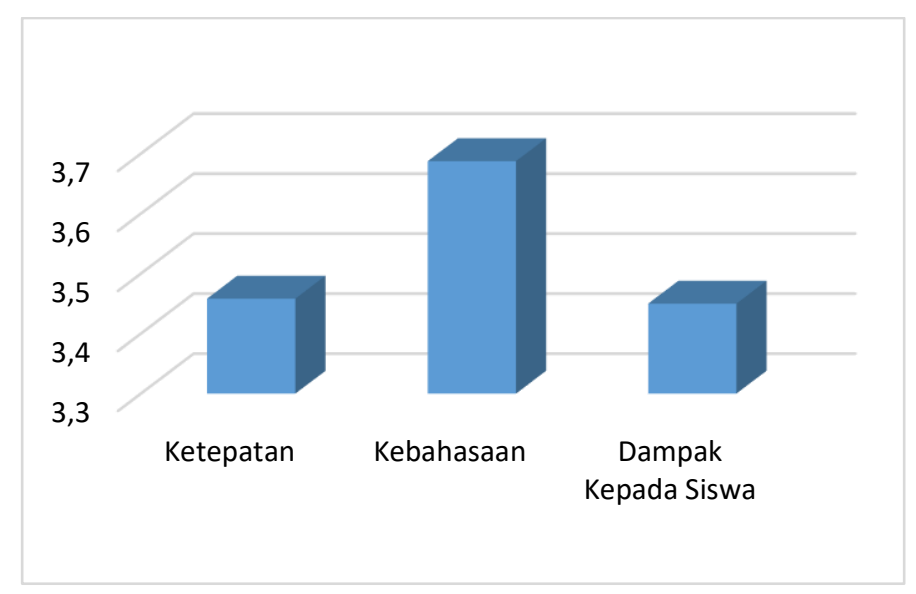

Gambar 3. Rerata skor validasi Materi

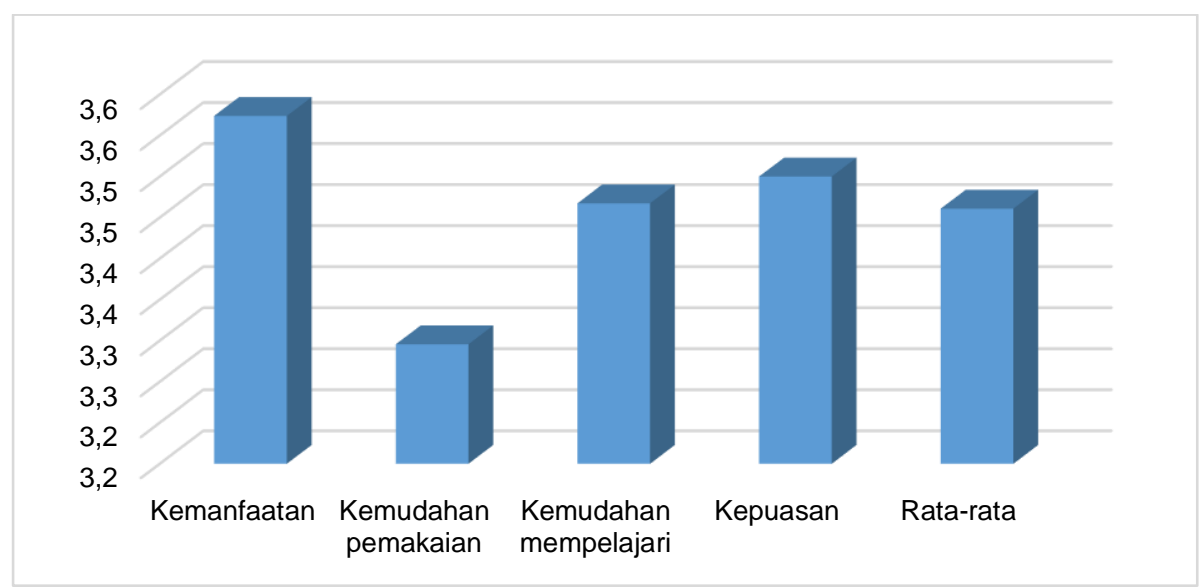

Gambar 4. Diagram hasil uji 
Uji keefektifan diujicobakan pada 23 peserta didik kelas $X$ yang sedang mendapatkan pembelajaran hukum Newton tentang gravitasi, hasil uji keefektifan e-modul dari keempat bagian yaitu: kemanfaatan, kemudahan pemakaian, kemudahan mempelajari dan kepuasan. Rata-rata skor keefektifan e-modul dari respon peserta didik dapat dilihat pada gambar 4 .

Berdasarkan Gambar 4 dihasilkan skor rata-rata 3.5. Skor ini masuk dalam kategori "Efektif", maka dapat dilihat bahwa e-modul yang dikembangkan dalam proses pendidikan guna mengefektifkan aktivitas dalam kegiatan belajar peserta didik (Wahyuningsih et al., 2021).

\section{SIMPULAN DAN SARAN}

Telah dihasilkan e-modul berbasis keterampilan berpikir hipotetikal deduktif yang layak dipakai oleh peserta didik. Kelayakan emodul serta fitur pendidikan pendukung ditinjau dari analisis validasi, analisis kelayakan, serta hasil respon peserta didik sebagai pengguna. Hasil validasi e-modul dari kelayakan materi diperoleh dari tiga aspek yaitu ketepatan, kebahasaan, dan dampak kepada peserta didik. Secara universal diperoleh hasil validasi sebesar 1 serta masuk dalam kategori valid dengan nilai reliabilitas sebesar 0.8 . Sedangkan dari kelayakan produk yang dilihat dari kemasan, pertimbangan produksi, pertimbangan siswa, pertimbangan materi dan pertimbangan guru diperoleh nilai validitas sebesar 1 dalam kategori valid dengan nilai reliabilitas sebesar 0.64 .

Hasil tata rata kelayakan e-modul dari nilai validasi materi sebesar 3.5 sedangkan rata rata validasi produk diperoleh sebesar 3.6. Dari kelayakan e-modul diperoleh kriteria sangat layak digunakan. Selanjutnya hasil analisis keefektifan e-modul yang diberikan kepada peserta didik diperoleh skor rata- rata 3.5. Skor ini masuk dalam kategori efektif.

\section{DAFTAR RUJUKAN}

Anugrahana, A. (2020). Hambatan, Solusi dan Harapan: Pembelajaran Daring Selama Masa Pandemi Covid-19 Oleh Guru Sekolah Dasar. Scholaria: Jurnal Pendidikan Dan Kebudayaan, 10(3), 282289.

Çavdar, G., \& Doe, S. (2012). Learning through writing: Teaching critical thinking skills in writing assignments. PS - Political Science and Politics, 45(2), 298-306. https://doi.org/10.1017/S1049096511002 137

Dhema, M., \& Jufriansah, A. (2021). Aktivitas
Dan Pemecahan Masalah Matematika Menggunakan Model Problem Based Learning Di SMK. JPMI (Jurnal Pembelajaran Matematika Inovatif), 4(1), 39-44.

https://doi.org/10.22460/jpmi.v4i1.39-44

Ekayani, N. L. P. (2021). Pentingnya Penggunaan Media Pembelajaran untuk Meningkatkan Prestasi Belajar Siswa. Jurnal Fakultas IImu Pendidikan Universitas Pendidikan Ganesha Singaraja, 2(1), 1-11.

Gunawan, S., \& Widiati, S. (2019). Tuntutan Dan Tantangan Pendidik Dalam Teknologi di Dunia Pendidikan Di Era 21. Prosiding Seminar Nasional Pendiidikan Program Pascasarjana, 594-601.

Lawson, A. (2003). Allchin's Shoehorn, or Why Science is Hypothetico-Deductive. Science \& Education, 12(3), 331-337. https://doi.org/10.1023/A:1024090727385

Nuniati, Prasetyo, E., \& Jufriansah, A. (2021). Pengembangan LKPD Terintegrasi Hots untuk Meningkatkan Motivasi Belajar Peserta Didik. ORBITA, Jurnal Hasil Kajian, Inovasi, Dan Pendidikan Fisika, 7(2), 366-370.

Octaviani, F. D., Haris, A., \& Yani, A. (2015). Pengaruh Model Pembelajaran Siklus Belajar Hipotetikal Deduktif Terhadap Keterampilan Berpikir Kritis Peserta Didik Kelas XI IPA SMA Negeri 4 Pinrang. Jurnal Sains Dan Pendidikan Fisika (JSPF), 11(1), 49-56.

Ramadoan, N., \& Sulisworo, D. (2018). Strategi berpikir hipotetikal deduktif dalam pengembangan keterampilan berpikir kritis pada pembelajaran fisika. Quantum: Seminar Nasional Fisika, Dan Pendidikan Fisika, 25, 351-357.

Sari, S. N., \& Haryono. (2021). Dampak Pembelajaran Online Pada Mata Pelajaran Sosiologi Di Masa Pandemi Covid-19 Di Sma 4 Pandeglang. Jurnal Pendidikan Sosiologi Dan Humaniora, 12(1), 51. https://doi.org/10.26418/jpsh.v12i1.46330

Suciati, N. N. A., Arnyana, I. G. A. N., \& Setiawan, I. B. P. (2014). Pengaruh Model Pembelajaran Siklus Belajar HipotetikDeduktif Dengan Setting 7E Terhadap Hasil Belajar IPA Ditinjau Dari Sikap IImiah Siswa SMP. E-Journal Program Pascasarjana Universitas Pendidikan Ganesha, 4(3), 1-14.

Sukaisih, R., Muhali, \& Asy'ari, M. (2020). Implementasi model reflectivemetacognitive learning untuk meningkatkan kemampuan berpikir kritis, 
keterampilan metakognisi dan kesadaran metakognisi. Empiricism Journal, 1(2), 75-95.

Sulisworo, D. (2016). The Contribution of the Education System Quality to Improve the Nation's Competitiveness of Indonesia. Journal of Education and Learning (EduLearn), 10(2), 127-138. https://doi.org/10.11591/edulearn.v10i2.3 468

Umayah, U., \& Riwanto, M. A. (2020). Transformasi Sekolah Dasar Abad 21 New Digital Literacy untuk Membangun Karakter Siswa Di Era Global. JURNAL PANCAR (Pendidik Anak Cerdas Dan Pintar), 4(1), 1-10.

Wahyuningsih, Jufriansah, A., Anomeisa, A. B., \& Rahmanisa, K. (2021). Strategy on The Effectiveness of Learning Outcomes of Manufacturing Calculus Using Edlink in The Covid-19 Pandemic. Eduma: Mathematics Education Learning and Teaching, 10(1), 39. https://doi.org/10.24235/eduma.v10i1.806 6

Yuangga, K. D., \& Sunarsi, D. (2020). Pengembangan Media dan Strategi Pembelajaran Untuk Mengatasi Permasalahan Pembelajaran Jarak Jauh di Pandemi Covid- 19. Jurnal Guru Kita, 4(3), 51-58. 